\title{
Między higieną szkolną a praktyką lekarską. Zadania lekarza szkolnego w Prusach (I poł. XX w.)
}

\section{Between school hygiene and medical practice. Duties of a school doctor in Prussia (1st half of the 20th century) \\ Summary:}

The first non-formalized samples of medical care for children at the primary schools, young people educating in vocational schools, young people at the secondary general-education schools and for people at the preparatory institutes as well as in the teacher education were already taken in the 80 s of the 19th century.

The duties of the district doctors, not yet school doctors, were limited to checking compliance regulations in the area of the general condition of school buildings and hygienic conditions in the abovementioned areas and buildings. Only in isolated cases did the doctors, mostly out of their own free will, attempt to carry out the regular medical examinations with the aim of recording physical and mental defects as well as the general health situation of children and adolescents of both sexes.

Despite the consciousness of the medical world, the scope of duties and obligations of school doctors was only defined and confirmed by state regulations in the first two decades of the 20th century. The school doctors became representatives of the public health care in educational institutions confirmed by government regulations. They were not only concerned with the observance of hygiene regulations, but above all with the prophylaxis of childhood diseases, infectious, venereal or occupational diseases (including vocational counseling), with the diagnosis of physical and mental dysfunctions and with the elimination of the pathologies associated with alcoholism. They carried out their tasks in close cooperation with the Youth Welfare Office. 
Słowa kluczowe: higiena szkolna, Prusy, pierwsza połowa XX w.

Keywords: school hygiene, Prussia, 1st half of the 20th century

\section{Od lekarza powiatowego do lekarza szkolnego}

Włączanie lekarzy w pruską strukturę szkolną, głównie w wielkich aglomeracjach miejskich, rozpoczęto w latach 80. XIX w. Proces legislacji zawodu lekarza szkolnego był jednak niezwykle powolny. W drugiej połowie XIX w. zadania lekarzy praktykujących w szkołach piastowali zazwyczaj lekarze powiatowi (Kresiarzt), ograniczały się one przede wszystkim do kontroli przestrzegania przepisów dotyczących warunków higienicznych w budynkach szkolnych oraz w trakcie zajęć. Jedynie sporadycznie, zazwyczaj z własnej woli, lekarze ci podejmowali się przeprowadzania badań okresowych celem ewidencjonowania defektów fizycznych i psychicznych oraz ogólnej sytuacji zdrowotnej wśród dzieci i młodzieży obojga płci. Postulat otaczania opieką lekarską uczniów szkół powszechnych i zawodowych podnoszono pod koniec XIX w. niejednokrotnie podczas międzynarodowych kongresów Niemieckiego Towarzystwa Opieki Zdrowotnej w Szkołach (Deutscher Verein für Schulgesundheitspflege). Komentowano go również szeroko na łamach powołanego w 1887 r. czasopisma dotyczącego propagowania higieny w szkołach - „Zeitschrift für Schulgesundheitspflege”. Dostrzeganie konieczności zaprowadzenia powszechnej opieki medycznej w szkołach nie skutkowało jednak wydaniem ze strony władz państwowych oczekiwanych przez środowisko lekarskie decyzji w postaci regulacji prawnych. Pod koniec XIX w. nadal brakowało jednolitego systemu opieki lekarskiej i socjalnej, jak też programów profilaktycznych i poradnictwa rodzinnego ${ }^{1}$.

Początek XX w. obfitował w międzynarodowe kongresy i konferencje poświęcone higienie szkolnej. Pierwszy z nich odbył się 7 kwietnia 1904 r. w Norymberdze (Kongress für Schulhygiene). Kolejne kongresy odbyły się w Londynie (1907 r.) i Paryżu (1910 r.). Poruszano m.in. tematy: zadania państwa w zakresie opieki lekarza szkolnego, eduko-

${ }^{1}$ T. Saretzki, Reichsgesundheitsrat und Preußischer Landesgesundheitsrat in der Weimarer Republik, Berlin 2000, s. 344-349; B. Ziegeler, Weibliche Ärzte und Krankenkassen. Anfänge ärztlicher Berufstätigkeit von Frauen in Berlin 1893-1935. Bd. 31, Weinheim 1993, s. 127; G. Hafemann, Die ärztliche Betreuung des Schulkindes. Organisation des schulärztlichen Dienstes, [w:] W. Hagen, E. Schröder (red.), Gesundheitsfürsorge, Stuttgart 1962, s. 83-94; I. Szagunn, Gesundheitsamt und Schule, „Pädagogisches Zentralblatt” 1931, H. 11, s. 12-16. 
wanie nauczycieli w zakresie higieny, rozwój dziecka w pierwszych latach nauki szkolnej czy choroby wieku dziecięcego².

Pierwsze wiążące rozporządzenie dotyczące opieki lekarskiej w szkołach publicznych na terenie Prus wydane zostało przez Ministerstwo Spraw Wewnętrznych i Gospodarki (Ministerium für Inneres und Wirtschaft) oraz Ministerstwo ds. Handlu i Rzemiosła (Ministerium für Handel und Gewerbe) dopiero w 1914 r. Zgodnie z nim pod kontrolą lekarzy szkolnych (Schularzt) miały pozostać dzieci i młodzież do 14. roku życia. Szacunkowa liczba lekarzy szkolnych na terytorium Prus wynosiła wówczas ok. 2 tys. Zapis ów był uzupełnieniem rozporządzeń dotyczących opieki nad młodzieżą wydanych w 1911 i 1913 r. Odnosiły się one do problemu wspomagania rozwoju fizycznego przez wprowadzenie zajęć usportawiających ${ }^{3}$. W szkołach powszechnych opiece lekarskiej podlegać mieli uczniowie obojga płci, w szkołach średnich zaś prawie wyłącznie młodzież męska. Wynikało to przede wszystkim z przyczyn politycznych i wprowadzenia odpowiednich regulacji w zakresie polityki zbrojeniowej. Wejście lekarzy do szkół zawodowych (Faschularzt) nastąpiło de facto przed wybuchem I wojny światowej. Ich zadania skoncentrowane były na prowadzeniu badań diagnostycznych i okresowych wśród młodzieży pomiędzy 14. a 18. rokiem życia. Do programów nauczania, jako obowiązkowe, wprowadzono wówczas zajęcia z gimnastyki ${ }^{4}$. W latach 20 . XX w. wprowadzono w szkołach zawodowych i średnich przedmioty, takie jak nauka o zdrowiu (Gesundheitslehre) i nauki o higienie w miejscu pracy (Gewerbehygiene) . $^{5}$

Wraz z reformą systemu oświaty w Niemczech w $1921 \mathrm{r}$. w struktury organizacji szkół powszechnych, zawodowych, średnich i wyższych, ponadto również instytucji przedszkolnych i pozaszkolnych, formalnie wprowadzono lekarzy szkolnych. W 1922 r. powołano Komisję ds. Opieki Zdrowotnej w Szkołach (Ausschuß für Schulgesund-

${ }^{2}$ Bundesarchiv Berlin (dalej: BAB), R 86, Reichsgesundheitsamt, sygn. 2392, Schulhygiene, Bd. 4 (1904-1912), b.p.; sygn. 5664, Schulhygiene, Bd. 5 (1904-1907), b.p.

${ }^{3}$ BAB, R 86, sygn. 2395, Reichsgesundheitsamt: Jugend- und Kinderpflege, Bd. 10, Schulärzte in Schulen und Fortbildungsschulen. Erlass des Ministers des Inneren und Ministers für Handel und Gewerbe 1914, b.p.; Ch. Sachße, F. Tennstedt, Geschichte der Armenfürsorge in Deutschland. Bd. 2, Stuttgart 1988, s. 99.

${ }^{4}$ P. Weindling, The Medical Profession, Social Hygiene and the Birth Rate in Germany, 1914-1918, [w:] R. Wall, J. Winter (red.), The Upheaval of War, Family, Work and Welfare in Europe, Cambridge-New York 1988, s. 434; T. Saretzki, dz. cyt., s. 348.

${ }_{5}^{5}$ Verhandlungen der XX. Jahresversammlung des Deutschen Vereins für Schulgesundheitspflege, Bonn 1925, s. 481. 
heitspflege $)^{6}$. Jej zadaniem było ponowne zdefiniowanie pojęcia higieny szkolnej w nawiązaniu do postępującego rozwoju nauk medycznych oraz techniki. Objęła ona problemy związane z: 1) właściwym wyposażeniem i przeznaczeniem budynków szkolnych, w zgodzie $\mathrm{z}$ elementarnymi wymogami higieny, 2) higieną zajęć szkolnych, 3) higieną zawodu nauczyciela, 4) wprowadzaniem elementów wiedzy o higienie do programów szkolnych, 5) wychowaniem fizycznym młodzieży szkolnej i 6) pracą lekarza w szkole ${ }^{7}$. Najważniejszą kwestią było jednak formalne określenie zadań lekarza szkolnego i dentysty szkolnego rozumianych $\mathrm{w}$ kontekście wychowania prozdrowotnego, we współpracy z administracją państwową, organizacjami społecznymi i charytatywnymi, mając na celu wspieranie młodzieży przez realizację zadań zmierzających do podniesienia poziomu kulturowego i standardów życia, głównie wśród niezamożnych warstw społeczeństwa ${ }^{8}$.

W kolejnych latach w szkołach powszechnych, średnich i wyższych postulat zatrudniania lekarzy szkolnych był realizowany zgodnie z założeniami. Z mocy prawa stali się oni przedstawicielami publicznej opieki zdrowotnej $\mathrm{w}$ instytucjach oświatowych, wypełniając również dotychczasową lukę w zakresie profilaktyki chorób wieku dziecięcego, chorób zakaźnych i wenerycznych, wczesnego rozpoznawania dysfunkcji fizycznych i psychicznych oraz eliminowania patologii związanej z alkoholizmem. Lekarze ci przejęli również zadania związane z wprowadzaniem właściwych nawyków żywieniowych. W 1911 r. zatrudnieni byli w zaledwie 4\% gmin w Prusach, w 1921 r. w 63\%, natomiast w 1926 r. w $81 \%$ gmin 9 . Z problemem braku kontroli lekarzy w zakresie opieki medycznej borykano się w kolejnych latach głównie w szkołach zawodowych. W 1929 r. opieką objętych było zaledwie 29\% uczniów w tego typu szkołach na terytorium Prus ${ }^{10}$. Celem przeciwdziałania niekorzystnej sytuacji w żeńskich szkołach zawodowych za-

${ }^{6}$ W. Grossmann, Aschenputtel im Schulalltag. Historische Entwicklung und Perspektiven von Schulsozialarbeit, Weinheim 1987, s. 77.

${ }^{7}$ J. Bennack, Gesundheit und Schule. Zur Geschichte der Hygiene im preußischen Volkschulwesen, Köln-Wien 1990, s. 284; M. Schretzmayer, Die Entstehung der Schulhygiene im höheren Bildungswesen Österreich von 1873 bis 1933, Wien 2008, s. 48-52. Por. L. Burgerstein, A. Netolitzky, Handbuch der Schulhygiene, Jena 1895.

${ }^{8}$ T. Saretzki, dz. cyt., s. 346-348; I. Szagunn, Gesundheitsfragen der Jugendlichen, „Das junge Deutschland” 1926, Bd. 20, s. 21-28.

${ }^{9}$ Ch. Sachße, F. Tennstedt, dz. cyt., s. 120.

${ }^{10}$ B. Ziegeler, dz. cyt., s. 31; I. Szagunn, Die schulärztliche Versorgung der Berufsschulen, „Die Berufsschule” 1930, H. 5, s. 191-195; E. Düntzer, Erfahrungen aus der Tätigkeit einer Berufsschulärztin, Stuttgart 1964, s. 2; A. Gottstein, Der Schularzt in der Fortbildungsschule, „Zeitschrift für Schulgesundheitspflege” 1914, Bd. 27, s. 127. 
trudniano kobiety-lekarki (Fachschulärztin), a pracujących uczniów szkół zawodowych włączono w powszechny system opieki kas chorych, co pozwalało na skuteczną walkę w zwalczaniu chorób zawodowych i zakaźnych, w tym gruźlicy. Lekarzom w szkołach zawodowych powierzono ponadto zadania związane $\mathrm{z}$ doradztwem zawodowym, w czym wspomagali lekarzy szkół powszechnych ${ }^{11}$.

Lekarze szkolni wspierani byli przez higienistki szkolne (Schulpflegerin, Schulschwester), które łączyły zadania pielęgniarek i opiekunek społecznych. Służyły pomocą w zakresie organizacji pracy lekarza szkolnego i pośredniczyły w kontaktach z urzędami zdrowia, sądami rodzinnymi, lokalnymi wydziałami opieki dla młodzieży oraz policją ${ }^{12}$.

W myśl regulacji Ministerstwa Spraw Wewnętrznych i Gospodarki koszta opieki nad dziećmi i młodzieżą były współfinansowane przez władze samorządowe - gminy i powiaty, które zobligowano do zapewnienia lekarzom szkolnym odpowiedniej siły pomocniczej, jak również pomieszczeń i wyposażenia, takich jak waga i przyrządy pomiarowe ${ }^{13}$.

\section{Zadania lekarzy szkolnych}

Początkowo zadania lekarzy powiatowych, jeszcze nie szkolnych, koncentrowały się na kontroli budynków szkolnych oraz przestrzegania zasad higieny w tychże. Władze miejskie zasięgały opinii lekarzy, planując budowę nowych gmachów szkolnych, w zakresie: kontrolowania placu budowy, jego otoczenia, stanu wody pitnej i planów budowlanych pod kątem zasad higieny. Na etapie tworzenia projektu nowej szkoły należało uwzględnić udział w zajęciach dzieci o specyficz-

${ }^{11}$ BAB, R 86, sygn. 2395, Bd. 10. Erlass des Ministers des Inneren und Ministers für Handel und Gewerbe 1914, b.p.; I. Szagunn, Die Rolle des Arztes bei der Berufswahl, „Die deutsche Berufserziehung” 1933, Bd. 48, s. 11-13; taż, Die Mittwirkung des Arztes bei der Berufswahl, [w:] W. Hellpach (red.), Die Schule im Dienst der Berufserziehung und Berufsberatung, Berlin 1927, s. 106-110. Por. P. Petersen, W. Zimmermann, Die Aufgaben des neuen Berufsschulwesens und die Berufsschulgemeinde, Jena 1925.

12 Geheimes Staatsarchiv Preußischer Kulturbesitz (dalej: GStA PK), R 76, Kultusministerium, VIII B, sygn. 2830, Die Hygiene in Schulen und Lehranstalten (19051914), k. 31; I. Szagunn, Schulpflegerinnen an höheren Schulen, „Zeitschrift für Schulgesundheitspflege und soziale Hygiene” 1920, Bd. 33, s. 154-157; b.n., Schülerfürsorge, [w:] A. Gottstein, L. Teleky (red.), Handbuch der Sozialen Hygiene und Gesundheitsfürsorge, soziale und private Versicherung, Berlin 1927, s. 6-8; G. Schreck Graf von Reischach, Konzepte und Grundpositionen - historische und international Aspekte der Bezüge von Jugendhilfe und Schule, Heidelberg 2006, s. 108.

${ }^{13}$ BAB, R 86, sygn. 1.7.7, Schulhygiene, Sport, Jugendpflege, Fürsorgeerziehung, Badenwesen, „Soziale Praxis“ 13 V 1925, Nr. 33. 
nych potrzebach edukacyjnych. Od lekarza wymagano również systematycznego sprawdzania stanu budynków szkolnych - zabezpieczenia wyjść ewakuacyjnych, stanu sal lekcyjnych (w tym oświetlenia), stanu podłóg i ławek szkolnych, ogrzewania, stanu korytarzy, spluwaczek i systemu wentylacji, garderób, toalet, sali gimnastycznej, placu zabaw i dostępności oraz wykorzystania materiałów dydaktycznych z zakresu higieny i zdrowia. Lekarz miał stać na straży dbałości o regulaminowe wypełnianie zasad higieny w placówkach oświatowych każde dziecko powinno było mieć do dyspozycji przestrzeń $1 \mathrm{~m}^{2}$, przy założeniu, że długość pomieszczeń lekcyjnych wynosiła $9 \mathrm{~m}$, szerokość $5,7 \mathrm{~m}$, a wysokości 3,2-3,5 m. Temperatura pomieszczenia nie powinna była być niższa niż 19 stopni. W trakcie przerw nakazywano wietrzenie sal. Codziennie miały być one zamiatane, raz w tygodniu gruntownie sprzątane. Do zadań lekarza szkolnego należało przeszkolenie dzieci i młodzieży oraz kształcenie nauczycieli w zakresie zasad higieny szkolnej ${ }^{14}$. Wśród młodzieży starszej - ze szkół zawodowych i średnich - prowadzić miał pogadanki, mające na celu zapobieganie alkoholizmowi, nikotynizmowi, oglądaniu nieobyczajnych plakatów i zdjęć, czytaniu niedozwolonej literatury, hazardowi, zagrożeniom $\mathrm{w}$ pracy zawodowej, na strzelnicy czy w niewskazanym towarzystwie ${ }^{15}$.

Do głównych zadań lekarza szkolnego należała dbałość o zdrowie dzieci i młodzieży, ich kondycję fizyczną i psychiczną. Był zobowiązany do systematycznego kontrolowania stanu zdrowia uczniów we wszystkich klasach szkolnych, w poszczególnych rocznikach, przynajmniej raz na dwa lata, później raz na rok, ponadto wszystkich nowych uczniów - dotyczyło to również dzieci w wieku przedszkolnym, które powinny zostać poddane badaniom w wieku 3, 5 i 7 lat - i tych, którzy opuszczali szkołę. Średnio dwa razy w miesiącu lekarz szkolny miał wizytować każdą szkołę, raz na kwartał, ewentualnie raz na pół roku każdą klasę. Wiązało się to również z poradnictwem zawodowym. W normalnym trybie lekarz zajmował się wizytacją wybranych klas,

${ }^{14}$ GStA PK, R 76, VIII B, sygn. 2828, Die Hygiene in Schulen und Lehranstalten (1870-1900), Übersicht über den Inhalt der auf den Erlass vom 25. Februar 1888 betr. Die Frage stärkerer Beteiligung von Ärzten an der Schulaufsicht, Berlin 1889, k. 85-89; sygn. 2839, Die Hygiene in Schulen und Lehranstalten (1914-1920), k. 33 (Schulgesundheitspflege. Anweisung der Königlichen Regierung zu Düsseldorf für die Lehrschaft und die Schulverwaltungen, Düsseldorf 1915); BAB, R 86, sygn. 5677, Jugendfürsorge-Ämter (1910-1923). Karten-Auskunftei des Fürsorgewesens mit Berücksichtigung der gesamten Sozialversicherung und der Kriegsfürsorge, H. 29, 11 IV 1923, Stuttgart, k. 5a-7b.

${ }_{15}$ BAB, R 86, sygn. 1.7.7, Schulhygiene, Sport, Jugendpflege, Fürsorgeerziehung, Badenwesen, Die Erlasse zum Schutze der Jugendlichen vor erziehungswürdigen Einflüssen, von Dr. Albert Hellwig, b.p. 
następnie badał dzieci, sprawdzał stan pomieszczeń szkolnych i na zakończenie przeprowadzał rozmowę z nauczycielem, wychowawcą. Lekarz szkolny był ponadto zobowiązany wydać rodzicom potwierdzenie ewentualnej sporządzonej przez niego diagnozy na piśmie, jeżeli prowadzenie konkretnego przypadku przejmował inny lekarz. Lekarze szkolni mieli możliwość uczestniczenia w konferencjach nauczycieli, prowadząc zajęcia seminaryjne w zakresie zasad higieny, jak też przedkładania wniosków do deputacji szkolnej w tym zakresie. Lekarz szkolny wchodził ponadto w skład Komisji Higieny Szkolnej (Hygienische-Schulkommission) ${ }^{16}$.

W latach 30. XX w. nowo przyjmowani uczniowie powinni byli zostać przebadani przez lekarza szkolnego $\mathrm{w}$ terminie do sześciu tygodni od rozpoczęcia nauki w szkole, pod kątem stanu zdrowia fizycznego i psychicznego - lekarz szkolny miał prawo odroczenia dziecka na okres jednego roku nauki szkolnej. Dzieci niebędące w pełni zdrowia znajdowały się w trakcie nauki w szkole pod kontrolą lekarza szkolnego. Decydował on też $\mathrm{w}$ konkretnych przypadkach o zwalnianiu z zajęć, tj. z ćwiczeń fizycznych i śpiewu, oraz czy np. z powodu upośledzenia narządu słuchu lub wzroku dzieci będą zajmowały specjalne miejsce w sali. Dzieci epileptyczne uczęszczać miały do szkoły, jeżeli ich choroba nie zaburzała toku prowadzonych zajęć. Przyjęcie lub zwolnienie z zajęć szkolnych następowało na podstawie orzeczenia lekarza o stanie zdrowia i wydaniu zgody w postaci zaświadczenia przez inspektora szkolnego $\mathrm{w}$ danym powiecie. Wszystkie informacje na temat zdrowia dziecka lekarz szkolny umieszczał w karcie zdrowia (Gesundheitsbogen/Gesundheitsschein), wstępną diagnozę dotyczącą choroby przekazywał kierownikowi szkoły, a następnie, jak wspomniano rodzicom, informował również Urząd ds. Młodzieży (Jugendamt). Karty zdrowia przechowywał nauczyciel i przedkładał w odpowiednim czasie lekarzowi szkolnemu. Przypadki zachorowań zgłaszane były do lekarza szkolnego przez kierownika lub nauczyciela. Na wniosek kierownika szkoły lekarz szkolny doglądać miał w wyjątkowych przypadkach dzieci chore $\mathrm{w}$ domach, jeżeli rodzice nie podejmą innej decyzji ${ }^{17}$. Karty zdrowia

${ }^{16}$ BAB, R 86, sygn. 5677, Jugendfürsorge-Ämter (1910-1923), k. 40; Staatsbibliothek Berlin (dalej: StaBi), Das Schularztwesen in Deutschland. Bericht über Ergebnisse einer Umfrage bei den größten Städten des Deutschen Reiches von Dr. med. Paul Schubert, Hamburg-Leipzig 1905 (mps); Stenografischer Bericht über die Verhandlungen des 22. Ordentlichen Brandenburgischen Städtetages in Potsdam, 18. und 19. September 1899, Frankfurt an der Oder (mps).

17 GStA PK, R 76, VIII B, sygn. 2843, Dienstanweisung für die Schulärzte (1935), k. 219 (Dienstanweisung für die Schulärzte in Beuthen OS). 
dzieci przechowywane były w osobnych kopertach i pozostawały do wglądu podczas dokonywania inspekcji szkolnych, jak również do dyspozycji lekarza szkolnego przy każdorazowym dokonywaniu kontroli lekarskiej. W wypadku opuszczenia szkoły przez dziecko, tj. przejścia do innej szkoły, karta zdrowia przesyłana była w ślad za nim ${ }^{18}$. Karty te zawierały informacje ogólne i szczegółowe dotyczące: budowy ciała (głowy, kręgosłupa, klatki piersiowej), stanu fizycznego (dobry, średni, niezadowalający), anomalii fizycznych (tj. niedokrwistość, niedobór ołowiu, inne), chorób wzroku (dalekowzroczność, krótkowzroczność, zez), chorób uszu, stanu jamy ustnej (uzębienie), wad wymowy (jąkanie się), chorób skóry, stanu organów wewnętrznych, defektów ogólnorozwojowych i chorób psychicznych ${ }^{19}$. Prowadzono również ogólne - klasowe - ankiety/karty zdrowia, obejmowały one:

- ogólną statystykę zachorowań (Erkrankungsstatistik) w postaci wywiadu dotyczącego przebytych przez uczniów chorób: ogólnych, gruźlicy, syfilisu, ewentualnych innych chorób; uchybień fizycznych poszczególne części ciała, chorób psychicznych,

- informacje z wizytacji lekarza szkolnego w klasie (schulärztliche Klassenbesichtigung), część ta była wypełniana przez nauczyciela. Dotyczyła ogólnych wskazań i zaleceń lekarza szkolnego odnośnie do pomieszczenia, w którym odbywały się zajęcia (odnotowywano: liczbę dzieci, wiek dzieci, liczbę godzin lekcyjnych, czas trwania zajęć), krótkiego wywiadu na temat stanu zdrowia dzieci w klasie - część wypełniali wspólnie nauczyciel i lekarz szkolny - dotyczyła ona kwestii pomieszczenia, które wizytował, tj. stanu podłóg, sufitu i ścian, oświetlenia naturalnego i sztucznego, wietrzenia pomieszczenia w sposób naturalny lub systemem wentylacji, sposobu ogrzewania pomieszczenia, stanu i przygotowania miejsca do mycia rąk, czystości sali i toalety, liczby ławek i ich jakości ${ }^{20}$.

Poza lekarzem szkolnym, w miarę postępującej specjalizacji nauk medycznych, do dyspozycji szkół wszystkich typów pozostawali lekarze specjaliści: okuliści, laryngolodzy, ortopedzi, logopedzi-fonia-

${ }_{18}$ GStA PK, R 76, VIII B, sygn. 2835, Die Hygiene in Schulen und Lehranstalt (1898-1903), Dienstordnung für die Schulärzte an den städtischen Volks- und Mittelschulen zu Wiesbaden, k. 23.

19 GStA PK, R 76, VIII B, sygn. 2835, Die Hygiene in Schulen und Lehranstalt (1898-1903), Jahresbericht über den schulärztlichen Überwachungsdienst an den Volkschulen zu Breslau, Breslau 1901, k. 175.

${ }^{20}$ GStA PK, R 76, VIII B, sygn. 2833, die Hygiene in Schulen und Lehranstalten (1922-1924), k. 9-11. 
trzy i dentyści, a w dyspozycji szkół specjalnych dodatkowo lekarze psychiatrzy. Opieka nad dziećmi chorymi dotyczyła również chorób narządów ruchu (wady postawy, kalectwo), chorób narządów zmysłu (problemy z utrzymaniem równowagi, problemy narządu słuchu), wad wymowy, chorób infekcyjnych, ze szczególnym uwzględnieniem gruźlicy czy moczenia nocnego ${ }^{21}$.

Lekarzy szkolnych zatrudniano na podstawie podań zarządów szkół, które przedkładano na ręce organu prowadzącego. To, czy lekarz pracował na cały etat, zależne było od liczby uczniów w szkole - jeżeli gmina liczyła powyżej 10 tys. uczniów, wówczas zatrudniano go na cały etat, jeśli poniżej - w charakterze lekarza nieetatowego. Otrzymywał pobory raz na kwartał, natomiast raz na rok pobierał dodatkowo honorarium, w zależności od liczby przebadanych uczniów. Władze poszczególnych rejencji, które ponosiły koszta tytułem zatrudniania lekarzy szkolnych, samodzielnie precyzowały zadania związane $\mathrm{z}$ jego nadzorem nad szkołami. Wszelkie uchybienia w pracy odnotowywano, informowano o tychże również odpowiednie urzędy. Jeżeli poza terminem ferii letnich chciał opuścić miejsce pracy na okres powyżej ośmiu dni lub zachorował, powinien był niezwłocznie poinformować władze gminy celem zapewnienia zastępstwa na okres nieobecności. Raz do roku (w maju) lekarze szkolni byli zobligowani do przedstawiania sprawozdań z działalności (Bericht über die schulärztliche Tätigkeit). Zawierały one: statystyczne podsumowanie wyników prowadzonych badań lekarskich (badań okresowych oraz uczniów nowo przyjętych), statystykę przeprowadzonych wizytacji, liczbę i rodzaj zdiagnozowanych przypadków zachorowań wraz z podaniem jednostek chorobowych, liczbę zwolnień z zajęć, liczbę powiadomień skierowanych do rodziców, liczbę kontroli lekarskich przeprowadzonych wśród dzieci i młodzieży znajdujących się pod opieką lekarza szkolnego oraz sumaryczne przedstawienie ewentualnych uwag. Negatywne spostrzeżenia, głównie w zakresie wizytacji pomieszczeń szkolnych i obejścia, lekarze szkolni odnotowywali w książce rewizyjnej (Revisionsbuch). W razie braku respektowania tych wskazań mieli prawo zgłoszenia niesubordynacji do deputacji szkolnych $^{22}$.

${ }^{21} \mathrm{StaBi}$, Der Schularzt von Dr. Werner Fischer-Defoy, Frankfurt am Main 1928 (mps).

${ }^{22}$ GStA PK, R 76, sygn. 2835, k. 24; sygn. 2843, k. 219; BAB, R 86, sygn. 5675, Schulärzte in Schulen und Fortbildungsschulen (1910-1918), b.p. 


\section{Lekarz szkolny w szkole zawodowej}

W szkołach zawodowych lekarz szkolny powinien był realizować szereg zadań z zakresu higieny pracy. Celem była profilaktyka przez eliminację złych nawyków zdrowotnych oraz zapewnienie właściwej opieki w miejscu pracy: 1) higiena indywidualna pracownika (konieczność mycia rąk, zawodowe choroby rąk, stosowanie środków toksycznych i trujących, zapoznanie się z zasadami antyseptyki, higiena ubioru), 2) higiena spożywania posiłków, ze szczególnym uwzględnieniem używek, tj. alkoholu i nikotyny, 3) higiena w relacjach z ludźmi, ze szczególnym uwzględnieniem gruźlicy i chorób zakaźnych, 4) higiena serca, 5) higiena narządów zmysłów oraz 6) higiena w miejscu zamieszkania, w miejscu pracy, w zakładzie, w warsztacie (bhp zawodu, niebezpieczeństwa ${ }^{23}$.

Zadaniem lekarzy realizujących praktykę w szkłach zawodowych było przeprowadzenie badań ogólnych, tj. badań fizykalnych, jak również określenie predyspozycji fizycznych, pod kątem przysposobienia do określonego zawodu. Prowadzili oni w tym celu preorientację zawodową przez pogadanki tematyczne. Szczególne poradnictwo dotyczyło osób z upośledzeniem kończyn dolnych i górnych. Według Rudolfa Handrocka zaledwie ok. 22\% zdolnych było podjąć pracę zawodową, $5 \%$ w ogóle. Lekarz szkolny pośredniczył w kontaktach między rodzicami a psychiatrą. Po przeprowadzeniu badań fizykalnych wskazywał odpowiedni dla ucznia zawód, tj.: stolarz, introligator, murarz, ślusarz, ogrodnik, szewc, hydraulik, tkacz, zamiatacz ulic, odprowadzający zanieczyszczenia, pakowacz, wyplatacz koszy, sklejacz torebek papierowych, goniec, pomocnik w sklepie, roznosiciel mleka. W przypadku osób z upośledzeniem fizycznym: woźnica, pomocnik w stajni, pracownik polowy. Dla dziewcząt przewidywano: prace na służbie lub w sklepie ${ }^{24}$.

Inną, niezwykle ważną kwestią była praca zawodowa dzieci w zakładach przemysłowych, szczególnie w drugiej połowie XIX w. Sytuacja ta wymusiła na ustawodawcy odpowiednie przepisy, gwarantujące dzieciom możliwość nauki i rozwoju. Obowiązkowo przez trzy lata, poczynając od 9. roku życia, powinny były uczęszczać regularnie do szkoły na zajęcia. Maksymalny czas pracy zakładał 10 godzin. Praca w nocy kończyć się miała przed godziną 5.00, a rozpoczynać po 21.00 . Przestrzegano wolnych niedziel i świąt. W 1890 r. w Berlinie odbyła

${ }^{23}$ [b.i.] Kriz, [b.i.] Horst, Zur Frage der Gewerbe-Schulärzte, „Die gewerbliche Fortbildungsschule" 1909, Jg. 5, Nr. 6, b.p.

${ }^{24} \mathrm{StaBi}, \mathrm{R}$. Handrock, Schularzt und Berufsberatung (mps), s. 1-4, 18, 28-30. 
się Międzynarodowa Konferencja dot. Ochrony Pracownika (Internationale Arbeiterschutzkonferenz), jej konsekwencją była ustawa wprowadzona 1 czerwca $1891 \mathrm{r}$. W myśl litery prawa zakazano pracy dzieci poniżej 13. roku życia w fabrykach. 14-latki mogły odtąd pracować maksymalnie sześć godzin, z półgodzinną przerwą, następującą po trzech godzinach pracy. Całkowicie zabroniono pracy dzieciom w zakładach przemysłowych w warunkach szkodliwych. Dzięki wsparciu państwa liczba dzieci w zakładach pracy zmniejszała się zasadniczo w kolejnych latach, w 1890 - 27,5 tys., 1892 - 11,2 tys. i w $1895-4,3$ tys. W myśl ustawy z 1903 r. przepisy objęły również dzieci pracujące na roli. Pracę dzieci poddano systematycznej kontroli. Każdemu dziecku założona została karta pracy, odnotowywano w niej skrupulatnie wszystkie dane. Brak było w ustawodawstwie odniesień do opieki zdrowotnej nad dziećmi z tej grupy ${ }^{25}$. W 1908 r. wprowadzono kolejne ograniczenia wieku dzieci pracujących. Dzieci 12-letnie mogły pracować trzy godziny, w ferie - cztery godziny. Praca mogła odbywać się w godzinach pomiędzy 8.00 a 20.00 . Zakładano również uczestnictwo dzieci w zajęciach lekcyjnych w godzinach przedpołudniowych, wówczas praca była zakazana. Po południu, między zakończeniem zajęć w szkole a podjęciem pracy, musiała upłynąć przynajmniej jedna godzina przerwy. W południe dzieci miały dwie godziny przerwy. Czas trwania pracy ustalono na maksymalnie 78 godzin tygodniowo. Celem zapewnienia odpoczynku niedziela i święta pozostawały dniami wolnymi od pracy ${ }^{26}$.

\section{Zadania szkoły w zakresie higieny}

Doraźnie o czystość i porządek w salach lekcyjnych dbać mieli nauczyciele poszczególnych przedmiotów nauczania, w szczególności zaś wychowawcy, celem zapewnienia prawidłowego rozwoju dzieci oraz wyrobienia podstawowych nawyków higienicznych. Do ich zadań należało regularne sprawdzanie, czy dzieci są umyte i uczesane. W przeciwnym razie nauczyciel zobligowany był przeprowadzić wywiad w środowisku rodzinnym dziecka. Jeżeli nie zapewniało ono środków czystości, dziecko otrzymywało je w szkole. Odpowiednia informacja była przekazywana policji miejskiej celem dalszego monitorowania sytuacji. Po ćwiczeniach fizycznych dzieci miały mieć zapewniony dostęp do łaźni, natrysków szkolnych. Zwracano uwagę,

\footnotetext{
${ }^{25}$ A. Lauer, Gewerblicher Kinderschutz, M. Gladbach 1889, s. 30-36.

${ }^{26}$ Zweck, Inhalt und Durchfuhrung des Kinderschutzgesetzes, „Darmstädter Tageblatt” 23 VII 1908, s. 4.
} 
żeby w szkole zdejmowały nakrycia głowy, nie dopuszczano noszenia chust i szali podczas zajęć. Dzieci zawszone były czasowo zwalniane z zajęć. Przypadki te również zgłaszano policji. Dzieci w danej klasie, w której została wykryta wszawica, kierowano na badania do lekarza szkolnego. Nauczyciel sprawdzał także czystość odzieży, szczególną uwagę przywiązywano do stanu obuwia. W szkole obuwie podlegało zmianie na tzw. obuwie lekkie (Zeugschuhe) lub pantofle. Podczas długich przerw w zimne dni dzieci i młodzież powinni byli zakładać płaszcze $^{27}$.

Dzieci w wielkich miastach winny były otrzymywać dziennie kubek mleka, wskazane było również zorganizowanie w gminach, przy wsparciu opieki społecznej, drugiego śniadania -1/3 lub 1 litra mleka. Nauczyciel zobligowany był do informowania, czy dzieciom z rodzin ubogich oraz tzw. słabowitym zapewniano mleko na koszt opieki społecznej. Dotyczyło to również typowania na wypoczynek na czas ferii, pobytów kuracyjnych i solankowych ${ }^{28}$.

Nauczyciel decydował o wyborze miejsca zajmowanego przez dziecko w klasie, co zależało od jego możliwości, ze szczególnym uwzględnieniem upośledzania wzroku, słuchu czy narządów ruchu. Należało zadbać o bezpieczeństwo dziecka podczas zajęć, podczas czytania i pisania odległość dziecka od książki, zeszytu czy tabliczki nie powinna była być większa niż $25-32 \mathrm{~cm}$. Należało zrezygnować z zajęć po zmroku, żeby nie obciążać narządu wzroku dziecka ${ }^{29}$.

Wyjście z klasy dziecka nie powinno być ograniczone $\mathrm{w}$ trakcie trwania zajęć. Przerwy trwać miały odpowiednio: krótka 10 min., 20 min. po drugiej i trzeciej godzinie lekcyjnej. Jeżeli zajęcia trwały dłużej, dziecko powinno mieć podczas dnia przynajmniej dwie godziny czasu wolnego celem odpoczynku i regeneracji sił. Przy temperaturze przekraczającej 25 stopni lekcje popołudniowe nie odbywały się. W godzinach popołudniowych zajęcia nie trwały dłużej niż 4 godziny $^{30}$.

Dzieci z gruźlicą wykluczano z nauki szkolnej celem odizolowania od dzieci zdrowych na podstawie rozporządzeń ministerstwa z 14 lipca 1884 i 20 maja 1898 r., z uwagi na ewentualne narażenie na bezpośredni kontakt. Szkoły przez lekarzy szkolnych zobligowane były

${ }_{27}$ GStA PK, R 76, VIII B, sygn. 2830, Die Hygiene in Schulen und Lehranstalten (1905-1914). Amtliches Schulblatt für der Regierungsbezirk Minden, Minden (1 X 1905 r.), k. 31 i kolejne.

${ }^{28}$ Tamże.

${ }^{29}$ Tamże.

${ }^{30}$ Tamże. 
do prowadzenia ewidencji dzieci chorych na gruźlicę, przygotowania punktów informacyjnych dla potencjalnych chorych i ich rodziców. Dla tej grupy organizowano zajęcia w placówkach sanatoryjnych oraz wychowawczo-leczniczych. Zalecano szczególną dbałość o przestrzeganie higieny w salach lekcyjnych i innych pomieszczeniach szkolnych celem wyrobienia odpowiednich nawyków dotyczących korzystania ze wspólnych naczyń szkolnych, wietrzenia i ogrzewania pomieszczeń, w perspektywie zaś wypracowania właściwych nawyków dotyczących rozwoju fizycznego przez ćwiczenia fizyczne, odpowiednią akcję profilaktyczną z wykorzystaniem plakatów czy ulotek oraz zajęcia z zakresu wiedzy o zdrowiu. Sprawy te podlegały kompetencji nauczyciela. W razie wykrycia w szkole ogniska choroby zakaźnej (tyfus, cholera) zarządzano dezynfekcję, której poddawano wszystkie pomieszczenia na terenie szkoły, w tym toalety ${ }^{31}$.

Opuszczającym progi szkoły wręczano publikacje (broszury) zawierające reguły zdrowego prowadzenia się w życiu dorosłym: „Willst du gesund sein? Unseren abgehenden Schülern zur Erinnerung an ihre Schulzeit und zur Beherzigung im Leben". Zawierała ona porady dotyczące właściwego odżywiania się profilaktyki przeciwgruźliczej, dbałości o higienę osobistą, porady w zakresie aktywności fizycznej - gimnastyki i higieny narządów zmysłów. Broszura przestrzegała przed alkoholizmem. Nakazywała również opiekę nad osobami chorymi. Porady dotyczyły również warunków domowych - dostępu do wody pitnej, zasad higieny w gospodarstwie domowym czy przygotowywania posiłków ${ }^{32}$.

\section{Bibliografia}

\section{Archiwalia}

Bundesarchiv Berlin

R 86, Reichsgesundheitsamt

sygn. 2392, Schulhygiene, Bd. 4 (1904-1912).

sygn. 2395, Reichsgesundheitsamt: Jugend- und Kinderpflege, Bd. 10,

Schulärzte in Schulen und Fortbildungsschulen. Erlass des Ministers des Inneren und Ministers für Handel und Gewerbe 1914. sygn. 2598, Jugendfürsorge (1906-1940). sygn. 5664, Schulhygiene, Bd. 5 (1904-1907).

31 Tamże; F. Lorenz, Das Tuberkulose als Volkskrankheit und Imre Bekämpfung durch die Schule. Eine Anweisung für die Lehrerschaft, Berlin 1909, s. 149.

${ }^{32}$ BAB, R 86, sygn. 2598, Jugendfürsorge (1906-1940), b.p. 
sygn. 5675, Schulärzte in Schulen und Fortbildungsschulen (1910-1918). sygn. 5677, Jugendfürsorge-Ämter (1910-1923).

sygn. 1.7.7, Schulhygiene, Sport, Jugendpflege, Fürsorgeerziehung, Badenwesen.

Geheimes Staatsarchiv Preußischer Kulturbesitz

R 76, Kultusministerium, VIII B sygn. 2828, Die Hygiene in Schulen und Lehranstalten (1870-1900). sygn. 2830, Die Hygiene in Schulen und Lehranstalten (1905-1914). sygn. 2833, die Hygiene in Schulen und Lehranstalten (1922-1924). sygn. 2835, Die Hygiene in Schulen und Lehranstalt (1898-1903). sygn. 2839, Die Hygiene in Schulen und Lehranstalten (1914-1920). sygn. 2830, Die Hygiene in Schulen und Lehranstalten (1905-1914). sygn. 2843, Dienstanweisung für die Schulärzte (1935).

\section{Staatsbibliothek Berlin}

Das Schularztwesen in Deutschland. Bericht über Ergebnisse einer Umfrage bei den größten Städten des Deutschen Reiches von Dr. med. Paul Schubert, Hamburg-Leipzig 1905 (maszynipis).

Handrock R., Schularzt und Berufsberatung (maszynipis).

Stenografischer Bericht über die Verhandlungen des 22. Ordentlichen Brandenburgischen Städtetages in Potsdam, 18. und 19. September 1899, Frankfurt an der Oder (maszynopis).

\section{Publikacje zwarte, artykuły}

Bennack J., Gesundheit und Schule. Zur Geschichte der Hygiene im preußischen Volkschulwesen, Köln-Wien 1990.

Burgerstein L., Netolitzky A., Handbuch der Schulhygiene, Jena 1895.

Düntzer E., Erfahrungen aus der Tätigkeit einer Berufsschulärztin, Stuttgart 1964.

Gottstein A., Der Schularzt in der Fortbildungsschule, „Zeitschrift für Schulgesundheitspflege” 1914, Bd. 27.

Gottstein A., Teleky L. (red.), Handbuch der Sozialen Hygiene und Gesundheitsfürsorge, soziale und private Versicherung, Berlin 1927.

Grossmann W., Aschenputtel im Schulalltag. Historische Entwicklung und Perspektiven von Schulsozialarbeit, Weinheim 1987.

Hagen W., Schröder E. (red.), Gesundheitsfürsorge, Stuttgart 1962.

Hellpach W. (red.), Die Schule im Dienst der Berufserziehung und Berufsberatung, Berlin 1927. 
Kriz [b.i.], Horst [b.i.], Zur Frage der Gewerbe-Schulärzte, „Die gewerbliche Fortbildungsschule” 1909, Jg. 5, Nr. 6.

Lauer A., Gewerblicher Kinderschutz, M. Gladbach 1889.

Lorenz F., Das Tuberkulose als Volkskrankheit und Imre Bekämpfung durch die Schule. Eine Anweisung für die Lehrerschaft, Berlin 1909.

Petersen P., Zimmermann W., Die Aufgaben des neuen Berufsschulwesens und die Berufsschulgemeinde, Jena 1925.

Sachße Ch., Tennstedt F., Geschichte der Armenfürsorge in Deutschland. Bd. 2, Stuttgart 1988.

Saretzki T., Reichsgesundheitsrat und Preußischer Landesgesundheitsrat in der Weimarer Republik, Berlin 2000.

Schreck Graf von Reischach G., Konzepte und Grundpositionen - historische und international Aspekte der Bezüge von Jugendhilfe und Schule, Heidelberg 2006.

Schretzmayer M., Die Entstehung der Schulhygiene im höheren Bildungswesen Österreich von 1873 bis 1933, Wien 2008.

Szagunn I., Die schulärztliche Versorgung der Berufsschulen, „Die Berufsschule" 1930, H. 5.

Szagunn I., Die Rolle des Arztes bei der Berufswahl, „Die deutsche Berufserziehung" 1933, Bd. 48.

Szagunn I., Gesundheitsamt und Schule, „Pädagogisches Zentralblatt" 1931, H. 11.

Szagunn I., Gesundheitsfragen der Jugendlichen, „Das junge Deutschland" 1926, Bd. 20.

Szagunn I., Schulpflegerinnen an höheren Schulen, „Zeitschrift für Schulgesundheitspflege und soziale Hygiene” 1920, Bd. 33.

Wall R., Winter J. (red.), The Upheaval of War, Family, Work and Welfare in Europe, Cambridge-New York 1988.

Verhandlungen der XX. Jahresversammlung des Deutschen Vereins für Schulgesundheitspflege, Bonn 1925.

Ziegeler B., Weibliche Ärzte und Krankenkassen. Anfänge ärztlicher Berufstätigkeit von Frauen in Berlin 1893-1935. Bd. 31, Weinheim 1993.

Zweck, Inhaltund Durchfuhrungdes Kinderschutzgesetzes, „Darmstädter Tageblatt” 23 VII 1908. 